\title{
Effect of dietary carbohydrate sources on apparent nutrient digestibility of olive flounder (Paralichthys olivaceus) feed
}

\author{
Md Mostafizur Rahman ${ }^{1}$, Kyeong-Jun Lee ${ }^{2}$ and Sang-Min Lee 1* $^{*}$
}

\begin{abstract}
Apparent digestibility coefficients (ADCs) of dry matter, crude protein, crude lipid, nitrogen-free extract, and energy in selected carbohydrate sources including wheat flour (WF), a-potato starch (PS), a-corn starch (CS), Na alginate $(A L)$, dextrin (DEX), and carboxymethyl cellulose (CMC) were determined for olive flounder. The olive flounder averaging $150 \pm 8.0 \mathrm{~g}$ were held in 300-L tanks at a density of 30 fish per tank. Chromic oxide was used as the inert marker. Feces were collected from the flounder by a fecal collector attached to a fish rearing tank. Apparent dry matter and energy digestibilities of flounder fed WF, PS, CS, and DEX diets were significantly higher than those of fish fed AL and CMC diets. Apparent crude protein digestibility coefficients of flounder fed PS and CS diets were significantly higher than those of fish fed AL, DEX, and CMC diets. Apparent crude lipid and nitrogen-free extract digestibility coefficients of flounder fed PS and DEX diets were significantly higher than those of fish fed WF, CS, AL, and CMC diets. The present findings indicate that PS and DEX could be effectively used as dietary carbohydrate energy compared to WF, CS, AL, and CMC for olive flounder.
\end{abstract}

Keywords: Flounder, Apparent digestibilities, Carbohydrate source

\section{Background}

Carbohydrates are valuable ingredient in formulated aquaculture diets (Rosas et al. 2000), and they can spare the use of protein as an energy source (Simon 2009). As the least expensive dietary energy source and good binding agent during the pelleting procedure (Arnesen and Krogdahl 1993; González-Félix et al. 2010), carbohydrate utilization by various species of cultured fish is getting more and more attention to nutritionists and food manufacturers (Niu et al. 2012). Carbohydrate digestion and capacity is variable among fishes where carnivorous fish are less able to utilize them than omnivorous and herbivorous species (Krogdahl et al. 2005). In general, carbohydrate inclusion in carnivorous fish diets is limited to $20 \%$ (NRC 2011). The efficiency of dietary carbohydrate utilization in fish diets has been examined for many species (Peres and Oliva-Teles 2002; Stone 2003; Lee et al. 2003; Wang et al. 2005).

\footnotetext{
* Correspondence: smlee@gwnu.ac.kr

${ }^{1}$ Department of Marine Biotechnology, Gangneung-Wonju National University, 7 Jukheon-gil, Gangneung, Gangwon-do 25457, South Korea Full list of author information is available at the end of the article
}

The use of dietary carbohydrate by fish depends on many factors including complexity, type, source, degree, and heat treatment of the carbohydrate; fish species; and environmental condition (NRC 1993; Hemre et al. 2002). However, its efficient utilization is linked to efficient digestibility, and the ability of fish to digest carbohydrate has been reported to be variable between species (Stone et al. 2003). Physiological variations associated with the feeding habits of the species, using the chemical features of the carbohydrate, lead to variable digestibility. This variability demonstrates physiological and functional differences of the gastrointestinal tract and associated organs of fish species (Krogdahl et al. 2005; González-Félix et al. 2010).

González-Félix et al. (2010) reported that carbohydrate digestibility in Florida pompano, Trachinotus carolinus, is approximately $50 \%$ emphasizing its restricted availability and therefore confined energy digestibility. Niu et al. (2012) investigated the dry matter and protein digestibility of some carbohydrate feedstuffs in juvenile tiger shrimp, Penaeus monodon. Deng et al. (2005) determined apparent digestibility coefficients (ADCs) 
of hydrolyzed potato starch for juvenile white sturgeon. But, no reports are available regarding the ADCs of carbohydrate sources for olive flounder. Information on apparent digestibility of ingredients in flounder diets is needed to improve diet formulation and reduce feed production costs. Therefore, this study was conducted to evaluate the ADC of different carbohydrate sources including wheat flour (WF), $\alpha$-potato starch (PS), $\alpha$-corn starch (CS), $\mathrm{Na}$ alginate (AL), dextrin (DEX), and carboxymethyl cellulose (CMC) for olive flounder.

\section{Methods}

\section{Experimental design and diet preparation}

A feeding experiment with three replicates was employed to investigate the effects of dietary carbohydrate source on nutrient digestibilities of olive flounder. Six experimental diets were formulated to contain $20 \%$ of each test ingredient such as WF, PS, CS, AL, DEX, and CMC. Ingredients and chemical composition of the experimental diets are presented in Table 1. Fish and squid liver oils were used as protein and lipid sources. Chromic oxide at a concentration of $0.5 \%$ dry matter was added as an inert marker. The diets were thoroughly mixed with $40 \%$ distilled water, pelleted by a wet pelleting machine, dried at room temperature for $24 \mathrm{~h}$, and stored at $-25^{\circ} \mathrm{C}$ until use.

\section{Fish and experimental condition}

The flounder were obtained from a private hatchery (Jeju Island, Korea) to the Marine and Environmental Research Institute of Jeju National University (Jeju, South Korea). They were acclimated to the laboratory condition for 2 weeks. Afterwards, the experimental fishes $(150 \pm 8.0 \mathrm{~g})$ were randomly distributed into 300-L cylindrical fiberglass tanks filled with $200 \mathrm{~L}$ of water at a density of 30 fish per tank in a flowthrough system prior to starting the digestibility test. The fish were hand-fed the experimental diets to visual satiety once a day for 10 days. Filtered seawater was supplied at a flow rate of $3 \mathrm{~L} / \mathrm{min}$ to each rearing tank. Fish rearing tanks had a sloping bottom leading to a centrally located drainage slot, and the effluent water was directed first over a fecal collection column and then to waste. Photoperiod was maintained on natural condition during the experimental period. The water temperature was maintained at $20.0 \pm 0.82{ }^{\circ} \mathrm{C}$.

\section{Fecal collection technique}

Three replicate groups of fish were carefully hand-fed the test diets to visual satiety once a day at 10:00 h by the same person during the experimental period. Two hours after feeding, the rearing tanks and collection columns were cleaned by sponges, and uneaten feed and fecal residues were removed. The next day, feces were
Table 1 Ingredients and chemical composition of the experimental diets

\begin{tabular}{|c|c|c|c|c|c|c|}
\hline & \multicolumn{6}{|c|}{ Diets } \\
\hline & WF & PS & CS & $\mathrm{AL}$ & DEX & CMC \\
\hline \multicolumn{7}{|l|}{ Ingredients (\%) } \\
\hline Fish meal & 61.0 & 61.0 & 61.0 & 61.0 & 61.0 & 61.0 \\
\hline Corn gluten meal & 5.0 & 5.0 & 5.0 & 5.0 & 5.0 & 5.0 \\
\hline Dehulled soybean meal & 5.0 & 5.0 & 5.0 & 5.0 & 5.0 & 5.0 \\
\hline Wheat flour & 20.0 & & & & & \\
\hline a-potato starch & & 20.0 & & & & \\
\hline a-corn starch & & & 20.0 & & & \\
\hline Na alginate & & & & 20.0 & & \\
\hline Dextrin & & & & & 20.0 & \\
\hline Carboxymethyl cellulose & & & & & & 20.0 \\
\hline Squid liver oil & 5.0 & 5.0 & 5.0 & 5.0 & 5.0 & 5.0 \\
\hline Vitamin premix $^{a}$ & 1.2 & 1.2 & 1.2 & 1.2 & 1.2 & 1.2 \\
\hline Mineral premix ${ }^{b}$ & 1.5 & 1.5 & 1.5 & 1.5 & 1.5 & 1.5 \\
\hline Vitamin C (50 \%) & 0.3 & 0.3 & 0.3 & 0.3 & 0.3 & 0.3 \\
\hline Vitamin E (25 \%) & 0.2 & 0.2 & 0.2 & 0.2 & 0.2 & 0.2 \\
\hline Choline salt (50 \%) & 0.3 & 0.3 & 0.3 & 0.3 & 0.3 & 0.3 \\
\hline $\mathrm{Cr}_{2} \mathrm{O}_{3}$ & 0.5 & 0.5 & 0.5 & 0.5 & 0.5 & 0.5 \\
\hline \multicolumn{7}{|c|}{ Nutrient content (dry matter basis) } \\
\hline Crude protein (\%) & 53.2 & 49.6 & 50.7 & 49.8 & 49.3 & 49.4 \\
\hline Crude lipid (\%) & 7.9 & 7.5 & 8.2 & 9.4 & 9.2 & 8.4 \\
\hline Ash (\%) & 13.8 & 13.1 & 13.9 & 17.8 & 14.1 & 17.0 \\
\hline $\mathrm{N}$-free extract $(\%)^{c}$ & 25.1 & 29.8 & 27.2 & 23.0 & 27.4 & 25.2 \\
\hline Gross energy (kcal/g diet) & 4.2 & 4.0 & 4.2 & 3.7 & 4.2 & 4.0 \\
\hline
\end{tabular}

${ }^{a}$ Vitamin premix contained the following amount which were diluted in cellulose (g/kg mix): DL-a-tocopheryl acetate, 18.8; thiamin hydrochloride, 2.7; riboflavin, 9.1; pyridoxine hydrochloride, 1.8; niacin, 36.4; Ca-D-pantothenate, 12.7; myo-inositol, 181.8; D-biotin, 0.27; folic acid (98\%), 0.68; p-aminobenzoic acid, 18.2; menadione, 1.8; retinyl acetate, 0.73 ; cholecalciferol, 0.003 ; and cyanocobalamin, 0.003

${ }^{\mathrm{b}}$ Mineral premix contained the following ingredients ( $\left.\mathrm{g} / \mathrm{kg} \mathrm{mix}\right): \mathrm{MgSO}_{4} \cdot 7 \mathrm{H}_{2} \mathrm{O}$, 80.0; $\mathrm{NaH}_{2} \mathrm{PO}_{4} \cdot 2 \mathrm{H}_{2} \mathrm{O}, 370.0 ; \mathrm{KCl}, 130.0$; ferric citrate, $40.0 ; \mathrm{ZnSO}_{4} \cdot 7 \mathrm{H}_{2} \mathrm{O}, 20.0$; Ca-lactate, 356.5; $\mathrm{CuCl}, 0.2 ; \mathrm{AlCl}_{3} \cdot 6 \mathrm{H}_{2} \mathrm{O}, 0.15 ; \mathrm{Kl}, 0.15 ; \mathrm{Na}_{2} \mathrm{Se}_{2} \mathrm{O}_{3}, 0.01$; $\mathrm{MnSO}_{4} \cdot \mathrm{H}_{2} \mathrm{O}, 2.0$; and $\mathrm{CoCl}_{2} \cdot 6 \mathrm{H}_{2} \mathrm{O}, 1.0$

${ }^{c}$ Calculated $=100-($ crude protein + crude lipid + ash $)$

collected from the fecal collection columns at 10:00 $\mathrm{h}$ for 10 days. The feces were immediately filtered with filter paper (Whatman \#1) for $60 \mathrm{~min}$ at $4{ }^{\circ} \mathrm{C}$ and stored at $-75{ }^{\circ} \mathrm{C}$ for chemical analyses. Fecal samples from each tank were pooled at the end of the experiment.

\section{Analytical methods}

Freeze-dried feed and feces were finely ground using a grinder. Fish scales were removed using a $300-\mu \mathrm{m}$ sieve before analysis. Crude protein was determined by the Kjeldahl method using an auto Kjeldahl System (Buchi, Flawil, Switzerland). Crude lipid was analyzed with ether extraction in a soxhlet extractor (SER 148, VELP Scientifica, Milan, Italy). Moisture content was determined with 
a dry oven at $105^{\circ} \mathrm{C}$ for $6 \mathrm{~h}$, and the ash content was determined after combustion at $550{ }^{\circ} \mathrm{C}$ for $4 \mathrm{~h}$ in a muffle furnace. Nitrogen-free extract (NFE) was calculated by difference. Gross energy was analyzed by an adiabatic bomb calorimeter (Parr, USA). Chromic oxide content of the experimental diets and fecal samples were determined by a wet-acid digestion method (Furukawa and Tsukahara 1966). All chemical analyses from each tank were performed in triplicates.

Apparent digestibility coefficients (ADCs) for dry matter, nutrient, and energy of the experimental diets were determined using the following equations:

$\operatorname{ADC}$ of dry matter $(\%)=\left(100-\left(\right.\right.$ dietary $\mathrm{Cr}_{2} \mathrm{O}_{3} /$ feces $\left.\left.\mathrm{Cr}_{2} \mathrm{O}_{3}\right) \times 100\right)$,

$\mathrm{ADC}$ of nutrients or energy

$$
=\left(1-\frac{\text { dietary } \mathrm{Cr}_{2} \mathrm{O}_{3}}{\text { feces } \mathrm{Cr}_{2} \mathrm{O}_{3}} \times \frac{\text { feces nutrient or energy }}{\text { dietary nutrient or energy }}\right) \times 100 \text {. }
$$

\section{Statistical analysis}

All data were subjected to one-way analysis of variance (ANOVA) using SPSS version 20.0 (SPSS Inc., Chicago, IL, USA). Significant differences $(p<0.05)$ among the means were determined using Duncan's multiple range test (Duncan 1955). Correlation of nutrients and energy was assessed using Pearson regression. All data were presented as mean \pm SE of three replicate groups.

\section{Results}

Apparent nutrient digestibility of flounder fed different dietary carbohydrate sources is presented in Table 2. Apparent dry matter and energy digestibilities of flounder fed WF, PS, CS, and DEX diets were significantly higher than those of fish fed AL and CMC diets. Apparent crude protein digestibility coefficients of flounder fed PS and CS diets were significantly higher than those of fish fed AL, DEX, and CMC diets. Apparent crude lipid and NFE digestibility coefficients of flounder fed PS and DEX diets were significantly higher than those of fish fed WF, CS, AL, and CMC diets.

\section{Discussion}

Estimation of ADC values for feedstuffs is an important aspect in screening the nutritive value of feed ingredients and formulation of nutritionally sufficient diets (Irvin and Tabrett 2005). In this study, dry matter digestibilities (65-78\%) of flounder fed the diets containing different carbohydrate sources were higher compared to those (48-63\%) of rockfish fed the diets containing $\alpha$-potato starch, $\beta$-potato starch, $\beta$-corn starch, and dextrin (Lee and Pham 2011) but similar to results (68-79 \%) for spiny lobster, Jasus edwardsii, fed WF, DEX, PS, and CMC (Simon 2009). The low dry matter digestibility of $\mathrm{CMC}$ in this study can be attributed to the high content of ash. Lee (2002) reported that dry matter digestibility of rockfish fed the different ingredients appeared to relate to the quantity and chemical composition of the carbohydrate used. It has been found that complexity of the carbohydrate significantly influences its utilization in the fish diet (Jobling 2001; Lee and Pham 2011). Stone et al. (2003) reported that simple carbohydrate has high dry matter digestibility compared to the complex kind.

ADC of protein in the present study ranged from 72 to $90 \%$. Niu et al. (2012) reported that apparent protein digestibility of wheat starch, sucrose, potato starch, maize starch, and dextrin diets ranged from 81 to $92 \%$ for juvenile tiger shrimp, $P$. monodon. Apparent crude protein digestibility of $\alpha$-potato starch, $\beta$-potato starch, $\beta$-corn starch, and dextrin diets ranged from 90 to $95 \%$ for juvenile and grower rockfish (Lee and Pham 2011). Niu et al. (2012) demonstrated that protein digestibility of potato starch diet was significantly higher than that of maize starch and dextrin diets. ADC of protein appeared to have a positive relationship with dry matter (DM) digestibility $(r=0.90, p<0.01)$ of the test diets. In the present study, low crude protein digestibility of CMC diet may be due to the accelerated passage of the digesta from the stomach of olive flounder (Yamamoto and Akiyama 1995).

NFE digestibility exhibited a significant correlation to DM digestibility $(r=0.76, p<0.01)$ of the test diets. Although the actual mechanism responsible for poor carbohydrate utilization in fishes has not been recognized,

Table 2 Apparent nutrient digestibility (\%) of olive flounder fed different dietary carbohydrate sources

\begin{tabular}{llllll}
\hline Diets & Dry matter & Crude protein & Crude lipid & NFE & Gross energy \\
\hline WF & $74.5 \pm 0.41^{c}$ & $89.3 \pm 0.17^{c d}$ & $81.4 \pm 0.29^{c}$ & $62.0 \pm 0.61^{b}$ & $78.8 \pm 0.35^{c}$ \\
PS & $75.4 \pm 0.29^{c}$ & $90.0 \pm 0.12^{d}$ & $89.6 \pm 0.12^{\mathrm{e}}$ & $76.7 \pm 0.29^{c}$ & $79.7 \pm 0.40^{c}$ \\
CS & $74.7 \pm 0.80^{c}$ & $89.9 \pm 0.31^{d}$ & $83.8 \pm 0.51^{d}$ & $59.4 \pm 1.31^{b}$ & $79.8 \pm 0.63^{c}$ \\
AL & $69.3 \pm 0.59^{\mathrm{b}}$ & $78.5 \pm 0.42^{\mathrm{b}}$ & $64.1 \pm 0.71^{\mathrm{a}}$ & $62.4 \pm 0.74^{\mathrm{b}}$ & $67.9 \pm 0.62^{\mathrm{b}}$ \\
DEX & $78.5 \pm 3.17^{c}$ & $87.3 \pm 1.86^{c}$ & $94.3 \pm 0.84^{\mathrm{f}}$ & $86.3 \pm 2.04^{\mathrm{d}}$ & $87.3 \pm 1.86^{\mathrm{d}}$ \\
CMC & $64.6 \pm 0.30^{\mathrm{a}}$ & $72.4 \pm 0.27^{\mathrm{a}}$ & $71.6 \pm 0.27^{\mathrm{b}}$ & $53.2 \pm 0.43^{\mathrm{a}}$ & $62.0 \pm 0.33^{\mathrm{a}}$ \\
\hline
\end{tabular}

Values (mean \pm SE of three replications) in the same column not having a common superscript are significantly different $(p<0.05)$ 
inferior digestion of carbohydrate in carnivorous fish might be attributed to the environment in which they evolved (McGoogan and Reigh 1996). Lee and Pham (2011) reported that NFE digestibility of $\alpha$-potato starch, $\beta$-potato starch, $\beta$-corn starch, and dextrin ranged from 20 to $56 \%$ for juvenile and grower rockfish. In this study, the apparent NFE digestibility values were 53 to $86 \%$. The highest NFE digestibility value obtained for DEX was $86 \%$, and the lowest value observed for CMC was $53 \%$. This result indicates that differences in NFE digestibility of the diets containing different carbohydrate sources might be due to their indigestible polysaccharide content (Lee and Pham 2011).

Regarding carbohydrate sources, low NFE digestibility of carbohydrates indicates that digestibility of carbohydrates may be attributed to their reduced solubility and to their impediment of $\alpha$-amylase activity. Generally, the fish has low ability in digestion of carbohydrates due to its specific carbohydrase enzyme (Jobling 2001). The effects of solubility and $\alpha$-amylase on digestibility of different carbohydrates have been reported in silver perch (Stone et al. 2003). Some researchers suggested that carbohydrates are mainly digested in the interior segment of the digestive tract of fish and depends on their solubility in the fluid of the digestive tract (Fange and Grove 1979; Lovell 1989). There is no available information on NFE digestibility of olive flounder to date. Hence, studies on the topic are necessary to elaborate the carbohydrate utilization of flounder.

ADC of energy ranged from 62 to $80 \%$ in this study. It has been noted that energy ADC of the dietary carbohydrates such as dextrin, gelatinized wheat starch, glucose, raw wheat starch, and raw pea starch seemed to be significantly influenced by carbohydrate kind (Stone et al. 2003). Dextrin has been reported to be a very good carbohydrate energy source and successfully digested by fish (Lee et al. 2003; Stone et al. 2003). Lee and Pham (2011) reported that $\alpha$-potato starch and dextrin appeared to be effectively digested by rockfish as carbohydrate energy source. ADC of energy appeared to have a positive correlation with DM digestibility $(r=0.96, p<0.01)$ of the test diets. In this study, ADC of energy for DEX was the highest among the ingredients tested. In contrast, ADC of energy was the lowest for CMC among those tested. The poor energy digestibility of CMC in this study may be because of insufficient non-protein energy in feeds.

\section{Conclusion}

Among the carbohydrates tested, PS and DEX could be effectively used as dietary carbohydrate energy compared to WF, CS, AL, and CMC for olive flounder.

\section{Acknowledgements}

This work was supported by a grant from the National Institute of Fisheries Science (R2016016) in Korea.

\section{Authors' contributions}

MMR analyzed the chemical composition and prepared the draft paper. KL manufactured the feed and conducted the feeding trial. SML designed this study, the feeding system, and the revised paper. All authors read and approved the final manuscript.

\section{Competing interests}

The authors declare that they have no competing interests.

\section{Author details}

'Department of Marine Biotechnology, Gangneung-Wonju National University, 7 Jukheon-gil, Gangneung, Gangwon-do 25457, South Korea. ${ }^{2}$ Department of Marine Life Sciences, Jeju National University, Jeju 63243, South Korea.

Received: 12 May 2016 Accepted: 19 May 2016

Published online: 03 June 2016

\section{References}

Arnesen P, Krogdahl $\AA$. Crude and pre-extruded products of wheat as nutrients sources in extruded diets for Atlantic salmon (Salmo salar L.) grown in sea water. Aquaculture. 1993;118:105-17.

Deng DF, Hemre GI, Storebakken T, Shiau SY, Hung SSO. Utilization of diets with hydrolyzed potato starch, or glucose by juvenile white sturgeon (Acipenser transmontanus), as affected by Maillard reaction during feed processing. Aquaculture. 2005;248:103-9.

Duncan DB. Multiple-range and multiple F-tests. Biometrics. 1955;11:1-42.

Fange R, Grove D. Digestion. In: Hoar WS, Randall DJ, Bretts JR, editors. Fish physiology. New York: Academic Press; 1979. p. 161-260.

Furukawa A, Tsukahara H. On the acid digestion method for the determination of chromic oxide as an index substance in the study of digestibility of fish feed. Bull J.jn Soc Sci Fish. 1966;32:502-6.

González-Félix ML, Davis DA, Rossi Jr W, Perez-Velazquez M. Evaluation of apparent digestibility coefficient of energy of various vegetable feed ingredients in Florida pompano, Trachinotus carolinus. Aquaculture. 2010;310:240-3.

Hemre Gl, Mommsen TP, Krogdahl A. Carbohydrates in fish nutrition: effects on growth, glucose metabolism and hepatic enzymes. Aquac Nutr. 2002;8:175-94.

Irvin SJ, Tabrett SJ. A novel method of collecting fecal samples from spiny lobsters. Aquaculture. 2005;243:269-72.

Jobling M. Feed composition and analysis. In: Houlihan D, Boujard T, Jobling M, editors. Food intake in fish. France: Blackwell Science; 2001.

Krogdahl A, Hamre Gl, Mommsen TP. Carbohydrates in fish nutrition: digestion and absorption in postlarval stages. Aquac Nutr. 2005;11:103-22.

Lee SM. Apparent digestibility coefficients of various feed ingredients for juvenile and grower rockfish (Sebastes schlegeli). Aquaculture. 2002;207:79-95.

Lee SM, Pham MA. Effects of carbohydrate and water temperature on nutrient and energy digestibility of juvenile and grower rockfish, Sebastes schlegeli. Asian-Australas J Anim Sci. 2011;24:1615-22.

Lee SM, Kim KD, Lall SP. Utilization of glucose maltose, dextrin and cellulose by juvenile flounder (Paralichthys olivaceus). Aquaculture. 2003;221:427-38.

Lovell T. Digestion and metabolism. In: Lovell T, editor. Nutrition and feeding of fish. New York: Van Nostrand Reinhold; 1989. p. 185-203.

McGoogan BB, Reigh RC. Apparent digestibility of selected ingredients in red drum (Sciaenops ocellatus) diets. Aquaculture. 1996;141:233-44.

National Research Council. Nutrient requirements of fish. Washington: National Research Council of the National Academy Press; 1993. p. 105.

National Research Council. Nutrient requirements of fish and shrimp. Washington: National Research Council of the National Academics; 2011. p. 363.

Niu J, Lin HZ, Jiang SG, Chen X, Wu KC, Tian LX, et al. Effects of seven carbohydrate sources on juvenile Penaeus monodon growth performance, nutrient utilization efficiency and hepatopancreas enzyme activities of 6-phosphogluconate dehydrogenase, hexokinase and amylase. Anim Feed Sci Technol. 2012;174:86-95. 
Peres $\mathrm{H}$, Oliva-Teles A. Utilization of raw and gelatinized starch by European sea bass (Dicentrarchus labrax) juveniles. Aquaculture. 2002;205:287-99.

Rosas C, Cuzon G, Gaxiola G, Arena L, Lemaire P, Soyez C, et al. Influence of dietary carbohydrate on the metabolism of juvenile Litopenaeus stylirostris. J Exp Mar Biol Ecol. 2000;249:181-98.

Simon CJ. The effect of carbohydrate source, inclusion level of gelatinized starch, feed binder and fishmeal particle size on the apparent digestibility of formulated diets for spiny lobster juveniles, Jasus edwardsii. Aquaculture. 2009;296:329-36.

Stone DAJ. Dietary carbohydrate utilization by fish. Rev Fish Sci. 2003;11:337-69. Stone DAJ, Allan GL, Anderson AJ. Carbohydrate utilization by juvenile silver perch, Bidyanus bidyanus (Mitchell). II. Digestibility and utilization of starch and its breakdown products. Aquac Res. 2003;34:109-21.

Wang Y, Liu YJ, Tian LX, Du ZY, Wang JT, Wang S, et al. Effects of dietary carbohydrate level on growth and body composition of juvenile tilapia, Oreochromis niloticusxO.aureus. Aquac Res. 2005;36:1408-13.

Yamamoto T, Akiyama T. Effect of carboxymethyl cellulose, a-starch and wheat gluten incorporated in diets as binders on growth, feed efficiency, and digestive energy activity of fingerling Japanese flounder. Fish Sci. 1995:61:309-13.

Submit your next manuscript to BioMed Central and we will help you at every step:

- We accept pre-submission inquiries

- Our selector tool helps you to find the most relevant journal

- We provide round the clock customer support

- Convenient online submission

- Thorough peer review

- Inclusion in PubMed and all major indexing services

- Maximum visibility for your research

Submit your manuscript at www.biomedcentral.com/submit
Biomed Central 